An Analysis About the Influence between Occupational Factors and Work Environment on

Abortus Occurrence in Female Workers at Pt. X Sidoarjo by Tri Martiana

Submission date: 11-Sep-2019 12:05PM (UTC+0800)

Submission ID: 1170625724

File name: KARIL_PROF_TRI_2019_8.pdf (377.64K)

Word count: 2930

Character count: 15564 


\title{
An Analysis About the Influence between Occupational Factors and Work Environment on Abortus Occurrence in Female Workers at Pt. X Sidoarjo
}

\author{
Putri Ayuningtias Mahdang ${ }^{1}$, Tri Martiana ${ }^{2}$, Rr. Soenarnatalina Melaniani ${ }^{2}$, Anung Sugihantono ${ }^{3}$ \\ 'Student in Magister of Occupational Health and Safety, ${ }^{2}$ Lecturer, Departement of Occupational Health and \\ Safety, Faculty of Public Health, Airlangga University, Campus C Mulyorejo Surabaya-Indonesia, \\ ${ }^{3}$ Direcrorate General of Public Health, Ministry of Health Republic Indonesia
}

\begin{abstract}
Abortus is secretion of the conception before being able to live outside the womb with weight less than 1000 grams or gestational age less than 20 weeks. The risk factors for the miscarriage occurrence are encountered in PT.X workers which located in Sidoarjo district, including the existence of company regulations to apply shift work for workers and workers' perceptions about their work environment. The purpose of this study was to analyze the effect of job risk factors such as working hours, work shifts, and work environment factors such as noise, temperature, and vibration with the occurrence of abortus in female workers at PT. X Sidoarjo District.
\end{abstract}

The design of this study was cross sectional with observational study type. The respondents of this study were female workers with total of 192 people. The independent variables of this research were work factors and work environment factors. The dependent variable in this study was the incidence of abortus in female workers.

A total $28.64 \%$ of the respondents had experienced abortus. Logistic regression analysis found that there was a significant correlation between work shift and abortus incidence $\quad(p=0.020)$ and between exposure of the machine-induced vibration and abortus occurrence $(\mathrm{p}=0.006)$.

We recommended for the company to make a schedule regulation about the work shift and taking routine enviromental measurements, sothe risk of abortion occurrence in female workers due to occupational factors and work environment can be minimized.

Keywords: Duration of Working Hours, Work Shifts, Physical Work Environment, Abortus Occurrence, Female Workers.

\section{Introduction}

Life and work are something that can't be separated, if people want to live then they have to work. For human, work is a basic need for the fulfillment of needs

\section{Corresponding author:}

Prof. Dr. Tri Martiana, dr., M.S.

E-mail: tri.martiana@fkm.unair.ac.id

Lecturer in Departement of Occupational Health and

Safety Faculty of Public Health, Airlangga University

Campus C Mulyorejo 60115, Surabaya-Indonesia and desires, both for men and women. Work is defined as an economic activity undertaken by a person with the intention of obtaining or help to obtaining an income or profit in his life. The more job opportunities which currently occur, does not rule out women entry into the job world 1 .

Along with the development of the industrial world, female and male workers are often exposed to various risk factors that potentially threaten their health, including reproductive health. WHO mentions reproductive health concerning processes, functions, and reproductive systems at the stage of life. Thus 
reproductive health is an important element for the health of both women and men ${ }^{2}$. One of the reproductive problems for working women is a pregnancy disorder in which case is the incidence of abortus. Abortus is the secretion of conception before being able to live outside the womb with fetal weight less than 1000 grams or gestational age less than 20 weeks ${ }^{3}$.

WHO data suggests an estimated 4.2 million abortuss occur annually in Southeast Asia, with details: 1.3 millions occur in Vietnam and Singapore, 750,000 to 1.5 million in Indonesia, 155,000 to 750,000 in Philippines, and 300,000 to 900,000 in Thailand, as well as no estimates of abortus in Cambodia, Laos and Myanmar. In Indonesia, the current prevalence of Abortus is currently estimated at $7-14 \%$ i.e 560,000 - 1,100,000 incidents of abortus. The number of abortus in Indonesia is quite high. It is estimated that the contribution of abortus to maternal mortality can reach $30-50$ percent. The most common pregnancy complication in pregnancy especially in the first trimester is abortus ${ }^{4}$. The main cause of maternal death are bleeding (60\%), infection (25\%), gestosis $(15 \%)$ and abortus, including bleeding in early pregnancy. As a result of the bleeding $28 \%$ can cause maternal death, it is unpredictable and the occurrence is very abrupt $\mathrm{t}^{14}$.

Several factors are predisposing for abortus such as parity factor and mother's age. The risk of abortus is higher with increased parity and maternal age. According to the author's opinion, the age of pregnant women will affect the incidence of abortus. The older the pregnant women the more likely the abortus will occur. The theory conveyed by Littler (2010) that is from a number of abortus that occurred, he found that if the mother is older than 35 years old then the risk factor affecting abortus is higher. The frequency of clinically detectable abortus is increased by 12 percent in women younger than 20 to 26 percent in those over 40 years old ${ }^{13}$.

One of the risk factors of abortus in working women who is pregnant arises from occupational activity and work environment called occupational risk factors ${ }^{5}$. Several previous studies have shown that long working hours with the work shift system and exposure to physical factors in the workplace, such as lifting and standing activities, can increase the risk in pregnant women ${ }^{6}$. Factors which is related to the female work environment such as exposure to an anesthetic gas, noise, temperature and vibration may be associated with a risk of spontaneous abortus ${ }^{7}$.

The older the women's age during pregnancy is a strong risk factor because it deals with the quality of the ovum rather than the woman's ability to give birth. However, miscarriage that occurs in the workplace is also not uncommon, this is due to the existence of known hazard factors and potentially cause the problem of pregnancy which is the occurrence of abortus . $^{6}$

The presence of reproductive health disorder experienced by female workers can lead to lack of work productivity resulting in inefficient production costs. This is due to the higher reproduction disorder experienced by female workers, then the level of likelihood of absenteeism will also be higher so it will decrease the value of work performance and productivity ${ }^{8}$.

The aim of this study was to analyze the influence of job risk factors such as working hours, work shifts, and work environment factors such as noise, temperature, and vibration with the occurrence of abortus in female workers at PT. X Sidoarjo District.

\section{Material and Method}

The design of this study is cross sectional with observational study type. The respondents of this study were female workers with total of 192 people. The independent variables of this research were job factors (long working hours and work shifts) and work environment factors (noise, temperature and vibration). While the dependent variable in this study was the incidence of abortus in female workers.

This study was conducted at PT. X located in Sidoarjo District and implemented from October to November 2017. PT. X is a company engaged in the manufacturing of plastics.

Data collection techniques were included general data, job history (working hours and work shifts), work environment data (noise, temperature, and vibration), and pregnancy history by filling out the questionnaire. Analytical methods were used descriptive analysis and bivariate analysis.

\section{Findings}

\section{Duration of Work}

The duration of respondent's working hours in this study was divided into two categories, namely < 
8 hours and $\geq 8$ hours. Most of the respondents in this study worked $\geq 8$ hours as many as $190(98.95 \%)$ and 2 respondents worked $<8$ hours $(1.04 \%)$.

\section{Working Shift}

In the company where the study was conducted, they applied shift work system for workers in the production (non-office) i.e morning shift, afternoon and night. Most respondents work with shift work system of 145 respondents (75.52\%). While a small percentage of respondents work without shift work system of 47 respondents $(24.47 \%)$.

\section{Noise}

Based on the result of the study, we found that most of the respondents feel that their work environment is noisy as many as 150 respondents (78.12\%) and 42 respondents $(21.87 \%)$ stated that their working environment is not noisy.

\section{Temperature}

Based on the result of the study, we found that most of the respondents feel that their working environment is hot and often feel swelter as 170 respondents (88.54\%) and 22 respondents $(11.45 \%)$ stated that they do not feel swelter at work.

\section{Vibration}

Based on the results of the study, we found that a small percentage of respondents work by using nonvibrating machines as much as 75 respondents (39.06\%) and 117 respondents (60.93\%) stated that they work by using a vibrating machine.

\section{Abortus}

A small percentage of respondents had experienced abortus were 55 respondents $(28.64 \%)$ and 137 respondents $(71.35 \%)$ had never had abortus.

Test Results of the Effect Between Occupational Factors and Work Environment on Abortus Occurrence in Female Workers

Table 1. The Test Results of the influence

\begin{tabular}{|c|c|c|c|c|}
\hline \multicolumn{2}{|c|}{ Independent Variable } & \multicolumn{3}{|c|}{ Dependent Variable } \\
\hline \multirow[b]{2}{*}{ Variable } & \multirow[b]{2}{*}{ Category } & \multicolumn{2}{|c|}{ Abortus Occurrence } & \multirow{2}{*}{$\begin{array}{l}p \text {-value } \\
(0.05)\end{array}$} \\
\hline & & $\begin{array}{l}\text { Yes } \\
N(\%)\end{array}$ & $\begin{array}{l}\text { No } \\
\text { N (\%) }\end{array}$ & \\
\hline \multirow{2}{*}{ Duration of Work } & $\geq 8$ working hours & $\begin{array}{l}55 \\
(28.94)\end{array}$ & $\begin{array}{l}135 \\
(71.05)\end{array}$ & \multirow{2}{*}{0,999} \\
\hline & $<8$ working hours & $\begin{array}{l}0 \\
(0)\end{array}$ & $\begin{array}{l}2 \\
(100)\end{array}$ & \\
\hline \multirow{2}{*}{ Working Shift } & Shift & $\begin{array}{l}48 \\
(33.10)\end{array}$ & $\begin{array}{l}97 \\
(66.89)\end{array}$ & \multirow{2}{*}{0,020} \\
\hline & Non Shift & $\begin{array}{l}7 \\
(14.89)\end{array}$ & $\begin{array}{l}40 \\
(85.10)\end{array}$ & \\
\hline \multirow[b]{2}{*}{ Noise } & Yes & $\begin{array}{l}42 \\
(27.81)\end{array}$ & $\begin{array}{l}109 \\
(72.18)\end{array}$ & \multirow[b]{2}{*}{0,625} \\
\hline & No & $\begin{array}{l}13 \\
(31.70)\end{array}$ & $\begin{array}{l}28 \\
(68.29)\end{array}$ & \\
\hline \multirow{2}{*}{ Temperature } & Yes & $\begin{array}{l}49 \\
(28.82)\end{array}$ & $\begin{array}{l}121 \\
(71.17)\end{array}$ & \multirow{2}{*}{0,880} \\
\hline & No & $\begin{array}{l}6 \\
(27.27)\end{array}$ & $\begin{array}{l}16 \\
(27.27)\end{array}$ & \\
\hline \multirow{2}{*}{ Vibration } & Yes & $\begin{array}{l}30 \\
(40)\end{array}$ & $\begin{array}{l}45 \\
(60)\end{array}$ & \multirow{2}{*}{0.006} \\
\hline & No & $\begin{array}{l}25 \\
(21.36)\end{array}$ & $\begin{array}{l}92 \\
(78.63)\end{array}$ & \\
\hline
\end{tabular}


The result of the test in Table 1 shows that the independent variables that have significant effect on the variable of abortus occurrence are work shift variables and vibration variables due to the exposure of the machine at work. It can be seen from the probability value (p-value) of logistic regression test of working shift variable is 0.020 and the vibration variable is 0.006 .

One of the occupational factors that affect the incidence of abortus in female workers is the presence of work shift in the work. Work shift includes rotation variable and irregular work schedule. Study showed that the more irregular hours a person has to work, the greater the circadian cycle changes, the greater the pressure on the worker so that it can interfere the reproductive system. Women who work on afternoon and night shifts, rotation or schedule changes require greater attention. Work shift is also associated with the increase of miscarriage in the first trimester, preterm birth, and low birth weight ${ }^{5}$.

Based on the results of the study above, we obtained the results of female workers who run the work shift never experienced the occurrence of abortus that is equal to $33.10 \%$ with a significance value of 0.020 . This study was in accordance with Eskenazi's (1994) study, based on a case-control study which found an increased risk of spontaneous abortus for work shift and work at night ${ }^{9}$. MacDonald et al also found that female workers who were working with the shift system may increase the risk of spontaneous abortus. Other studies conducted in China have also found that women who work with irregular working hours or rotation shift systems will increase the risk of miscarriage ${ }^{10}$.

The mechanism that may underlies the causal relationship between night work and miscarriage is the recurrence of circadian rhythm in night workers and is associated with the decrease of melatonin secretion from lack of sleep. This can interfere sex hormone homeostasis, implantation and fetal growth. In addition, if this thing continues to occur during pregnancy it is known to increase the risk of spontaneous abortus ${ }^{11}$. This theory is supported by study conducted in Thailand which showed that work shift will lead to the emergence of irregular working hours. It may be associated with the increased risk of spontaneous abortus and reduced fertility. The mechanism which involved in the process may include changes in circadian rhythm along with hormonal concentration changes, which may affect both the conception and normal development of the fetus.
The cohort study on Nurse Health showed significantly increased estradiol levels and decreased melatonin excretion after several nights of work?

Abortus provides general symptom of abdominal pain due to uterine contraction, bleeding and along with the expenditure of all or part of the conception. The forms of bleeding vary greatly in small amounts and last for a long time, then at the same time in large amounts with clots, and as a result of bleeding can cause symptoms such as shock, increasing pulse, low blood pressure, anemic appearance, and cold fingertips ${ }^{4}$.

The vibration which felt by the body due to the use of the machine while working contributes to the occurrence of various reproductive problems, especially in pregnant women. In addition to causing impaired menstruation, exposure to the vibration of the engine can also cause miscarriage 5 . Based on the results, we obtained that respondents exposed by a vibrating machine experienced abortus as much as $40 \%$ with a significance value of 0.006 . This study is supported by a study conducted in America which stated that persistent exposure to vibration and noise in pregnant women can increase the risk of negative reproductive effects such as infertility, menstrual disorders, spontaneous abortus and premature birth. Exposure to vibration can cause impaired blood circulation in the pelvic area of pregnant women $^{12}$.

The effect of vibration released from noise are rarely studied, however, one study in Europe showed that women who are often affected by vibrations resulting from their work can cause serious problems for their reproductive health such as toxemia, complications of labor and may even increase perinatal mortality ${ }^{12}$.

\section{Conclusion}

As much 55 respondents had (28.64\%) had experienced abortion in their life.

Most of the respondents work with $\geq 8$ hours duration and have experienced abortion incidence by 55 respondents (28.94\%). While respondents who work with a working time $<8$ hours, only 2 people and never experienced abortion.

Most of the respondents who work in work shift and have experienced abortion occurrence by 48 respondents $(33.10 \%)$. 
Most of the respondents who felt their working environment is noisy and have experienced abortion is 42 respondents $(27.81 \%)$.

Most respondents who felt their working environment is hot and often feel swelter at work and have experienced abortion is 49 respondents (28.8\%).

A small percentage of respondents who work with a vibrating machine were constantly exposed to engine vibrations and have experienced abortion incidence are 30 respondents (40\%).

Based on the result of statistical test, there was a significant effect between work shift, and vibration exposure on the occurrence of abortion with p-value $<0,05$. Work shift will results in irregular working hours. It may be associated with the increase of spontaneous abortion and reduced fertility risk. In addition, persistent vibration and noise in pregnant women may increase the risk of negative reproductive effects such as infertility, menstrual disorders, spontaneous abortion and premature birth.

\section{Conflict of Interest: None}

Source of Funding : Departement of Occupational Health and Safety, Public Health Faculty, Airlangga University, Surabaya, Indonesia

Ethical Clearance: The data was collected after the study proposal passed the ethical clearance and passed by Health Research Ethics Commission of Faculty of Public Health Airlangga University. All study respondents have been given explanation and information about the purpose and method of this study and have signed the form of willingness to be a respondent.

\section{References}

1. Lestari, Y. (2010). Reproductive Health Behavior in Women Smokers at Surakarta City. Final Assignment. Sebelas Maret University

2. Amirudin M. (2003) Health and Women's Reproductive Rights. Jakarta: SMK Grafika Desa Putera

3. Manuaba. (2009). Family Planning Understanding Women's Reproductive Health Issue 2. Jakarta: EGC
4. Meti D. (2012). Characteristics of Pregnant Women in Abortion. Nursing Journal, Volume VIII, No. 2, ISSN $1907-0357$

5. Health Ministry Republic Indonesia (Kementerian Kesehatan RI). (2016). Guidelines for Reproductive Health at Work. Directorate of Occupational Health. Department of Health RI: Jakarta

6. Jens Peter E Bonde, MD, Kristian Tore Jørgensen, $\mathrm{PhD}$, Matteo Bonzini, MD, and Keith T Palmer, MD. (2013). Risk of miscarriage and occupational activity: a systematic review and meta-analysis regarding shift work, working hours, lifting, standing and physical workload. Scand J Work Environ Health. 2013 July 1; 39(4): 325-334.

7. Boivin JF. (1997). Risk of spontaneous abortion in women occupationally exposed to anaesthetic gases: a meta-analysis. Occupational and Environmental Medicine 1997;54:541-548

8. Harsetianingrum RA. (2015). Risk Analysis of the Incidence Risk of Menstrual Disorders in Female Workers at PT. XYZ Sidoarjo. Final Assignment. Airlangga University

9. Talamanca, Irene F. (2006). Occupational risk factors and reproductive health of women. Occupational Medicine 2006;56:521-531

10. Knutsson A. (2003). Health disorders of shift workers. Occupational Medicine 2003;53:103-108

11. Schernhammer ES, Rosner B, Willett WC, Laden F, Colditz GA, Hankinson SE. (2004). Epidemiology of urinary melatonin in women and its relation to other hormones and night work. Cancer Epidemiol Biomarkers Prev ; 13:936-943.

12. Hafez ES. (2014). Spontaneous Abortion: Springer Verlag

13. Rochmawati PN. (2013). Factors affecting abortus in Central Hospital dr. Soeradji Tirtonegoro Klaten. Publication Manuscript: Muhammadiyah University Surakarta.

14. Masitoh S, Hamidah. (2013). Dominant Factors Associated With Imminent Abortion Occurrence. Journal of Science \& Technology of Health Sciences, Volume 1, Number 1, September 2013, page : 29-33. 
An Analysis About the Influence between Occupational Factors and Work Environment on Abortus Occurrence in Female Workers at Pt. X Sidoarjo

ORIGINALITY REPORT

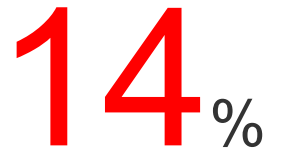

SIMILARITY INDEX

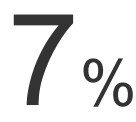

INTERNET SOURCES
$5 \%$

PUBLICATIONS
$\%$

STUDENT PAPERS

PRIMARY SOURCES

1 Submitted to Universitas Negeri Semarang

Student Paper

2 www.fkm.unair.ac.id Internet Source

\section{3}

I. Figa-Talamanca. "Occupational risk factors and reproductive health of women", Occupational Medicine, 12/01/2006

Publication

4 eprints.soton.ac.uk Internet Source

5 www.indianjournals.com

Internet Source

6 Submitted to Arvada West High School Student Paper

7 Keeling s Fetal and Neonatal Pathology, 2015. 
$9 \quad$ Kay Teschke. "Exposure to anesthetic gases

and congenital anomalies in offspring of female

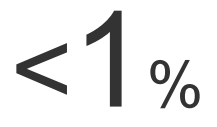
registered nurses", American Journal of

Industrial Medicine, 07/06/2010

Publication

\section{0}

Submitted to London Metropolitan University

Student Paper

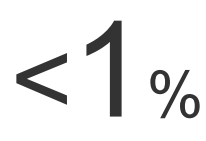

11 onlinelibrary.wiley.com

Internet Source

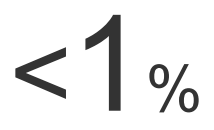

12 M. Barba, A. Cavalleri, H.J. Schünemann, V.

Krogh et al. "Reliability of Urinary 6-

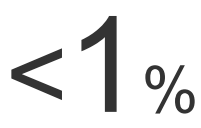

sulfatoxymelatonin as a Biomarker in Breast

Cancer", The International Journal of Biological

Markers, 2018

Publication

13

Elizabeth A. Whelan, Christina C. Lawson,

Barbara Grajewski, Eileen N. Hibert, Donna

Spiegelman, Janet W. Rich-Edwards. "Work

Schedule During Pregnancy and Spontaneous

Abortion", Epidemiology, 2007

Publication

Submitted to London School of Hygiene and

Tropical Medicine 
Exclude quotes

Off

Exclude matches

Off

Exclude bibliography

Off 
An Analysis About the Influence between Occupational Factors and Work Environment on Abortus Occurrence in Female Workers at Pt. X Sidoarjo

GRADEMARK REPORT

FINAL GRADE

$/ 100$
GENERAL COMMENTS

Instructor

\section{PAGE 1}

\section{PAGE 2}

PAGE 3

PAGE 4 